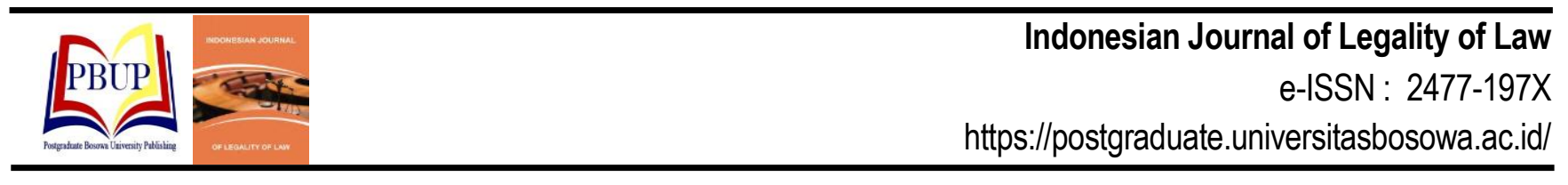

\title{
KENDALA DALAM PELAKSANAAN FUNGSI BALAI PEMASYARAKATAN DALAM PERLINDUNGAN HAK ASASI MANUSIA PADA SISTEM PERADILAN ANAK
}

\author{
Obstacles in the Implementation of Correctional Center Functions in the Protection of Human Rights in \\ Justice System of Children
}

\author{
Nuryuli Nurdin ${ }^{1}$, Baso Madiong ${ }^{2}$, Yulia A. $\operatorname{Hasan}^{3}$ Hamid $^{2}$ \\ ${ }^{1}$ Magister Ilmu Hukum Program Pascasarjana Universitas Bosowa \\ ${ }^{2}$ Program Studi Ilmu Hukum Program Pascasarjana Universitas Bosowa \\ Email: nuryulinurdin1976@gmail.com
}

Diterima: 10 Januari 2021/Disetujui: 01 Juni 2021

\begin{abstract}
ABSTRAK
Penelitian ini bertujuan untuk mengetahui Pelaksanaan Fungsi Balai Pemasyarakatan (BAPAS) Makassar Dalam Perlindungan Hak Asasi Manusia Pada Sistem Pidana Anak dan Kendala Balai Pemasyarakatan dalam Perlindungan Hak Asasi Manusia Pada Sistem Peradilan Anak. Penelitian merupakan penelitian normatif. Metode Pengumpulan Data melalui wawancara dan dokumentasi. Teknis Analisis data ini merupakan analisis kualitatif. Hasil penelitian menunjukkan bahwa Balai Pemasyarakatan kelas I Makassar sebagai salah satu penegak hukum khususnya dalam pembimbingan terhadap anak nakal menjalankan perannya tersebut melalui tiga tahap, yaitu tahap Pra ajudikasi, tahap ajudikasi dan tahap Post ajudikasi. Faktor kendala yang dihadapi dalam pelaksanaan Fungsi Balai Pemasyarakatan (BAPAS) antara lain kelemahan aturan hukum yang berlaku terhadap tindak pidana anak, kurangnya koordinasi diantara sesama aparat penegak hukum, rendahnya kualitas sumber daya manusia di BAPAS, and kurang Sarana dan Prasarana yang memadai. Mengakibatkan pelaksaan Fungsi Balai Pemasyarakatan (BAPAS) kurang optimal, dan alokasi anggaran dana yang sangat minim.
\end{abstract}

Kata Kunci: Balai Pemasyarakatan, Hak Asasi Manusia, Sistem Peradilan Anak

\begin{abstract}
This study aims to determine the implementation of the function of Makassar Correctional Center (BAPAS) in the Protection of Human Rights in the Criminal Justice System of Children and the Obstacles of the Correctional Center in the Protection of Human Rights in the Justice System of Children. This research is normative research. Data collection methods were through interviews and documentation. Technical analysis of the data is a qualitative analysis. The results showed that Correctional Center Class I Makassar as one of the law enforcers, especially in guiding delinquents carried out their roles in three stages, which are the Pre-adjudication stage, the adjudication stage and the Post-adjudication stage. Obstacles faced in the implementation of the function of Correctional Center (BAPAS) are weaknesses in the rule of law that applies to the crimes of children, lack of coordination among law enforcement officials, low quality of human resources at BAPAS, and lack of adequate facilities and infrastructure. As a result, the implementation of the function of Correctional Center (BAPAS) is not optimal, and the budget allocation for funds is very minimal.
\end{abstract}

Keywords: Correctional Center (BAPAS), Human Rights, Justice System of Children

\section{PENDAHULUAN}

Balai Pemasyarakatan adalah lembaga yang membimbing klien (anak) atas wewenang yang dimilikinya. Sehingga Teori pengawasan merupakan salah satu fungsi masyarakat yang belum mengetahui apa fungsi, tugas, dan peran dari Balai Pemasyarakatan tersebut. Untuk mengetahui apakah segala sesuatu berjalan sesuai dengan rencana yang telah ditetapkan (Vivtor M Situmorang dan jusuf juhrif, 1995). Lahirnya Undang-undang Nomor 11 Tahun 2012 tentang Sistem Peradilan Pidana Anak memperkuat eksistensi Balai Pemasyarakatan (BAPAS) dalam proses peradilan.
BAPAS melalui petugas pembimbing pemasyarakatan tidak hanya menjadi instansi yang memberikan tugas untuk melakukan penelitian kemasyarakatan berkaitan dengan anak yang terlibat dalam perkara pidana sebagaimana yang pernah diatur dalam undang-undang pengadilan anak. Tetapi melalui undang-undang sistem peradilan pidana anak ini, BAPAS menjadi salah satu unsur penting dalam proses penyelesaian tindak pidana yang dilakukan atau melibatkan anak. Dalam undang-undang sistem pengadilan pidana anak mengedepankan upaya untuk menghindarkan anak dari proses peradilan (diversi). 
Pelaksanaan proses peradilan anak cenderung tidak sesuai dengan undang-undang yang mengikat para institusi khususnya BAPAS. Hal ini terlihat dari hasil pemantauan oleh Komisi Perlindungan Anak Indonesia (KPAI) Kota Makassar pada Tahun 2018 terhadap BAPAS yang ada di Kota Makassar, di mana KPAI mendapatkan laporan bahwa terdapat beberapa penyimpangan seperti mayoritas anak tidak didampingi penasehat hukum dan Pembimbing Kemasayarakatan (BAPAS) selama proses peradilan, mayoritas putusan hakim pidana penjara, banyak anak terampas haknya selama proses peradilan, diantaranya hak pendidikan, hak kesehatan, hak untuk berkreasi, dan anak jalanan yang menjadi anak berkonflik dengan hukum seringkali ditahan karena tidak ada yang menjamin (Berita ANtara New, Edisi Maret 2019).

Di samping itu Pendampingan Kemasyarakatan (PK) tidak dapat melakukan pendampingan secara penuh sebagaimana mestinya kepada anak dalam menjalani proses peradilan. Hal ini antara lain disebabkan oleh keterbatasan jumlah PK yang dimiliki BAPAS Makassar, sehingga seorang PK harus mendampingi beberapa orang anak yang menjalani proses peradilan yang seringkali lokasinya jauh di luar Kota Makassar.

BAPAS melalui petugas pembimbing pemasyarakatan tidak hanya menjadi instansi yang memberikan tugas untuk melakukan penelitian kemasyarakatan berkaitan dengan anak yang terlibat dalam perkara pidana sebagaimana yang pernah diatur dalam undang-undang pengadilan anak. Tetapi melalui undang-undang sistem pengadilan pidana anak ini, BAPAS menjadi salah satu unsur penting dalam proses penyelesaian tindak pidana yang dilakukan atau melibatkan anak. Dalam undang-undang sistem pengadilan pidana anak mengedepankan upaya untuk menghindarkan anak dari proses peradilan (diversi).

Pelaksanaan proses peradilan anak cenderung tidak sesuai dengan undang-undang yang mengikat para institusi khususnya BAPAS. Hal ini terlihat dari hasil pemantauan oleh Komisi Perlindungan Anak Indonesia (KPAI) Kota Makassar pada Tahun 2018 terhadap BAPAS yang ada di Kota Makassar, di mana KPAI mendapatkan laporan bahwa terdapat beberapa penyimpangan seperti mayoritas anak tidak didampingi penasehat hukum dan Pembimbing Kemasayarakatan (BAPAS) selama proses peradilan, mayoritas putusan hakim pidana penjara, banyak anak terampas haknya selama proses peradilan, diantaranya hak pendidikan, hak kesehatan, hak untuk berkreasi, dan anak jalanan yang menjadi anak berkonflik dengan hukum seringkali ditahan karena tidak ada yang menjamin (Berita Antara New, Edisi Maret 2019).

\section{METODE}

Jenis penelitian yang digunakan adalah penelitian normative. Penelitian hukum normatif dimaksud untuk mengkaji serta menelaah norma-norma hukum dalam UndangUndang Nomor 11 Tahun 2012 serta peraturan perundangundangan lain yang ada kaitannya.

Penelitian dilakukan dengan mengambil lokasi di Balai Pemasyarakatan (BAPAS) Kelas I Makassar. Sebagai tindak lanjut dalam memperoleh data-data sebagaimana yang diharapkan, maka penulis melakukan teknik pengumpulan data yang berupa penelitian Pustaka (library research) dan penelitian lapangan (field research). Proses pengumpulan data terhadap suatu penelitian yang penulis lakukan, maka harus memiliki cara atau teknik untuk mendapatkan data atau informasi yang baik dan terstruktur serta akurat dari setiap apa yang diteliti, sehingga kebenaran informasi data yang diperoleh dapat dipertanggungjawabkan.

a. Wawancara

Interview atau yang sering juga disebut wawancara atau kuisioner lisan, adalah sebuah dialog yang dilakukan oleh pewawancara untuk memperoleh informasi dari terwawancara (nara sumber) yaitu Pembimbing Kemasyarakatan pada Balai Pemasyarakatan, Komisi Perlindungan Anak, Penyidik pada Kepolisan Resort Kota Besar Makassar dan Hakim pada Pengadilan Negeri Makassar.

b. Studi Dokumentasi

Studi pustaka dan dokumentasi biasanya digunakan untuk memperoleh informasi yang berbentuk berbagai catatan dari berbagai pihak berupa buku, leaflet, pamphlet, surat kabar, katalog, foto, dan catatan lainnya yang berkaitan dengan karya yang dikaji, sehingga diperoleh data-data yang dapat dipertanggungjawabkan kebenarannya. Bahkan tidak menutup kemungkinan, penulis juga mencari data dokumen melalui internet yang tetap memperhatikan kebenaran informasinya.

\section{HASIL DAN PEMBAHASAN}

\subsection{Pelaksanaan fungsi Balai Pemasyarakatan Makassar dalam perlindungan Hak Asasi Manusia pada sistem peradilan pidana anak}

Undang-Undang Nomor 11 Tahun 2012 Tentang Sistem Peradilan Pidana Anak dalam pendampingan kemasyarakatan mempunyai dasar hukum yang kuat dalam tugasnya membuat litmas, hadir dalam pendampingan sidang anak dan membimbing klien (anak yang berkonflik dengan hukum). Selain dengan pengawasan BAPAS mempunyai peran dan fungsi dalam melaksanakan penelitian kemasyarakatan yang digunakan sebagai bahan pertimbangan oleh Penyidik dalam proses teori keadilan di tingkat pengadilan.

a. Pembimbing dan Pendampingan Balai Pemasyarakatan Makassar dalam Perlindungan Hak Asasi Manusia.

Dalam pelaksanaan fungsi Balai Permasyarakatan digunakan pengawasan pula sebagai salah satu bahan pertimbangan hakim dalam memutus perkara anak yang berkonflik dengan hukum sebagaimana tercantum dalam Pasal 60 Ayat (3) Undang-Undang Nomor 11 Tahun 2012 Tentang Sistem Peradilan Pidana Anak. Apabila kewajiban tersebut tidak dilaksanakan oleh hakim maka terdapat implikasi yuridis berupa putusan batal demi hukum (Pasal 60 Ayat (4) UndangUndang Nomor 11 Tahun 2012 Tentang Sistem Peradilan Pidana Anak). Seperti yang dijelaskan juga oleh Sambas bahwa Anak berkonflik dengan hukum yang melewati tahapan-tahapan pengadilan tanpa kehadiran pendamping atau salah satunya BAPAS cenderung untuk terjerumus kembali kedalam pelanggaran baik itu dengan kasus yang sama ataupun dengan kasus yang berbeda (Sambas, 2013).

Pembimbing dan Pendampingan Balai pemasyarakatan dalam perlindungan anak diantaranya:

1. Pihak Lapas melakukan litmas terlebih dahulu seperti mengetahui identitas, bakat, kronologis, keluarga dari anak yang mendapatkan pembebasan bersyarat maupun cuti bersyarat; 
2. Surat permintaan dari Lapas bahwa anak sudah layak untuk mendapatkan pembebasan bersyarat (PB) ataupun ciri bersyarat (CB);

3. PK langsung ke LP, Rumah anak;

4. Home visit (pembimbingan kemasyrakatan mengunjungi anak untuk mendapatkan informasi perkembangan dari anak dalam pergaulan, sosialisasi maupun mental dari anak tersebut;

5. Mengetahui apa yang dibutuhkan oleh anak seperti program kerja bagi laki-laki seperti bengkel yang mana bekerja sama dengan pihak Balai Latihan Kerja dan Kementerian Tenaga Kerja;

6. Adapun kegiatan yang dilakukan Bapas dalam bimbingan anak pemasyarakatan salah satu satunya penyuluhan narkoba, program penyuluhan ini merupakan barang-barang terlarang yang saat ini muda ditemukan dan tidak sedikit yang menjadi pengguna narkoba adalah usia atau remaja di mana masa-masa transisi dari masa kanak-kanak ke masa dewasa.

Dalam pelaksanaan pembimbingan pada waktu anak datang berkunjung melakukan bimbingan kepada pembimbing kemasyarakat, anak diberikan kemandirian pada bimbingan kepribadian pembimbing kemasyarakatan menanyakan kegiatan yang dilakukan oleh anak, mengingatkan anak supaya tidak mengulangi tindak pidana yang pernah dilakukannya serta memberikan motivasi kepada anak.

Bagi anak yang tidak melakukan wajib lapor maka, pembimbing kemasyarakatan akan melakukan teguran dengan memberikan surat panggilan dan melakukan kunjungan kerumah anak (home visit). Setelah bimbingan berakhir PK membuat laporan singkat evaluasi bimbingan dan surat keterangan tersebut diserahkan pada anak dan orang tua anak, sedangkan semua berkas pembimbingan disimpan di kantor BAPAS.

Bahwa pelaksanaan bimbingan yang diberikan oleh BAPAS kepada anak, berkas-berkas tersebut terdiri dari surat Keputusan (SK) pembebasan bersyarat, maupun cuti bersyarat dari Kanwil Kementerian Hukum dan Ham telah sesuai dengan peraturan yang berlaku. Kemudian setelah itu bagi anak yang menjadi tanggung jawab BAPAS wajib melapor ke BAPAS satu bulan sekali bagi yang mendapatkan cuti bersyarat $(\mathrm{CB})$ dengan adanya wajib lapor tersebut yang mana supaya petugas BAPAS yang menangani masalah anak bisa mengontrol perkembangan dari setiap anak tersebut.

Perlindungan hak anak yang berhadapan dengan hukum dalam konteks HAM Internasional merupakan salah satu bagian dari serangkaian kewajiban yang harus dipenuhi oleh Negara yaitu untuk; menghormati (to respect), melindungi (to protect), dan memenuhi (to fulfill). Secara normative berlandaskan pada standar Hak Asasi Manusia Internasional maupun konstitusi (termasuk ketentuan HAM secara nasional) dan secara operasional ditujukan untuk memajukan pelaksanaan HAM.

Data dari BAPAS dalam pelaksanaan fungsi Balai Pemasyarakatan Makassar dalam perlindungan Hak Asasi Manusia pada sistem peradilan pidana anak diantaranya:
Tabel 1

Data Jumlah Anak Dalam Balai Pemasyarakatan Makassar Dalam Perlindungan Hak Asasi Manusia, Tahun 2020

\begin{tabular}{ccc} 
No & Jenis Kasus & $\begin{array}{c}\text { Tahun } 2020 \text { (Bulan September, Oktober, } \\
\text { November, Desember) }\end{array}$ \\
\hline 1 & Perampokan & 365 \\
2 & Pencurian & 363 \\
\hline & Total & 728 \\
\hline
\end{tabular}

Sumber: Balai Pemasyarakatan Makassar Dalam Perlindungan Hak Asasi Manusia

Dari data pada tabel 1 menunjukkan jenis tindak pidana yang dilakukan anak dalam dari perkembangan setiap tahun dapat di rata-ratakan jumlah tindak pidana yang dilakukan anak hampir sama dimana pada tahun 2020 terdapat 728 tindak pidana anak dan yang terbanyak adalah tindak pidana perampokan sebanyak 365 kasus, tidak pidana pencurian sebanyak 363 kasus dan pada tahun 2020 sampai pada bulan September, Oktober, November, Desember 2020 ada sebanyak 728 kasus tindak pidana anak kasus pencurian dan perampokan.

Kasus perampokan yang dilakukan anak adalah kasus tertinggi dalam waktu tahun 2020 terakhir dalam wilayah Balai Pemasyarakatan Makassar Dalam Perlindungan Hak Asasi Manusia data ini menunjukkan adanya fenomena anak melakukan tindak pidana yang terdesak secara ekonomi untuk melakukan kejahatan. Kewajiban untuk menghormati, melindungi dan memenuhi Hak Anak, masing-masing mengandung unsur kewajiban aparat penegak hukum dan masyarakat untuk bertindak (obligation to conduct) serta kewajiban untuk berdampkan (obligation toresult).

Menurut Sri Wahyuni, Sebagai Pembimbing Kemasyarakatan pada Balai Pemasyarakatan Makassar (Wawancara 12 Oktober 2020) bahwa penyidik anak wajib meminta saran dari pembimbing Kemasyarakatan selaku petugas pendampingan. Dimana dalam setiap tahapan diberikan bantuan hukum. Bantuan hukum terhadap Anak sebagai pelaku tindak pidana dalam sistem peradilan pidana di kota Makassar terdiri atas tiga tahapan, yaitu tahap penyidikan, tahap penuntutan, dan tahap pemeriksaan di persidangan, pada penelitian ini penulis mengkaji pemberian bantuan hukum kepada anak telah dilakukan sesuai dengan ketentuan peraturan perundang-undangan, peneliti melakukan pengamatan dan analisa terhadap pemberian bantuan hukum kepada anak.

Data pada polrestabes Makassar yang terjadi dalam tahun 2018-2020 pelaku anak yang diduga telah melakukan tindak pidana, berdasarkan data catatan yang ada oleh penyidik di Polrestabes Makassar khususnya laporan Unit PPA Polrestabes Makassar, terdapat 574 kasus Anak sejak Tahun 2018 sampai dengan Bulan November Tahun 2020

Tabel 2

Data Anak yang berkonflik dengan Hukum Polrestabes Makassar Tahun 2018-2020

\begin{tabular}{llll}
\hline No & Tahun & Jumlah Kasus & Persentase \% \\
\hline 1 & 2018 & 196 & $1,96 \%$ \\
\hline 2 & 2019 & 206 & $2,06 \%$ \\
\hline 3 & 2020 & 172 & $1,72 \%$ \\
\hline \multirow{3}{*}{ Jumlah : } & \multicolumn{2}{c}{$5,74 \%$} \\
\hline
\end{tabular}

Sumber Data: Polrestabes Makassar November 2020

Berdasarkan data pada tabel 2 menunjukkan jenis tindak pidana yang dilakukan anak dalam wilayah hukum polrestabes Makassar dari perkembangan setiap tahun dapat di rata- 
ratakan jumlah tindak pidana yang dilakukan anak hampir sama dimana pada tahun 2018 terdapat 196 (1,96\%) tindak pidana anak dan yang terbanyak adalah tindak pidana pencurian sebanyak 96 kasus, pada tahun 2019 terdapat 206 $(2,06 \%)$ tindak pidana anak dan yang terbanyak tidak pidana pencurian sebanyak 89 kasus dan pada tahun 2020 sampai pada bulan November 2020 ada sebanyak 172 (1,72\%) kasus tindak pidana anak sebanyak 72 kasus pencurian.

Kasus pencurian yang dilakukan anak adalah kasus tertinggi dalam waktu tiga tahun terakhir dalam wilayah hukum polrestabes Makassar data ini menunjukkan adanya fenomena anak melakukan tindak pidana yang terdesak secara ekonomi untuk melakukan kejahatan. Selanjutnya dalam tabel 3 menyajikan data tahap pemeriksaan apakah didampingi oleh penasehat hukum data bersumber dari polrestabes Makassar selama tahun 2018-2020.

\section{Tabel 3}

Jumlah Anak Dalam Penampingan Pemasyarakatan (BAPAS) Tahun 2018-2020

\begin{tabular}{clcccc}
\hline No & $\begin{array}{c}\text { Anak yang didampingi } \\
\text { Penasihat Hukum }\end{array}$ & $\begin{array}{c}2020 \\
\text { (November) }\end{array}$ & 2019 & 2018 & Jml \\
\hline 1 & $\begin{array}{l}\text { Mendapatkan } \\
\text { Pedampingan }\end{array}$ & 5 & 4 & 6 & 15 \\
2 & $\begin{array}{l}\text { Pemasyarakatan (BAPAS) } \\
\text { Tidak mendapat } \\
\text { pendampingan } \\
\text { Pemasyarakatan (BAPAS) }\end{array}$ & 167 & 202 & 190 & 559 \\
\hline & 172 & 206 & 196 & 574
\end{tabular}

Sumber Data: Balai Pemasyarakatan Kelas I Makassar (BAPAS) November 2020

Berdasarkan data table 3 memperlihatkan bahwa dari total 574 jumlah anak yang diproses sebagai pelaku tindak pidana pada tahap penyidikan, hanya 15 orang yang mendapat pendampingan dari BAPAS selama rentan waktu 2018-2020, data ini menunjukkan sedikitnya penerima bantuan hukum dalam wilayah hukum Kota Makassar. Tingginya tingkat kejahatan anak ini menunjukkan perlunya pendampingan dari BAPAS dalam proses pemeriksaan anak, pemberian pendampingan Pemasyarakatan dari BAPAS gratis atau cumacuma kepada anak merupakan pilihan yang dapat di berikan untuk menjamin hak-hak tersangka pada proses hukum kepada masyarakat.

"Tindak pidana yang melibatkan anak berhadapan dengan hukum meningkat dari tahun 2019 dibandingkan dengan tahun 2020," ujar Waka Reskrim Polres Kota Makassar Kompol Sugeng di Makassar, (Wawancara, 15 November 2020), bahwa Data Satuan Reskrim Polres Kota Makassar mencatat sudah ada seratus tujuh puluh dua kasus kriminalitas secara keseluruhan dan sebagianya sudah dilimpahkan kepenuntutan yang melibatkan anak di bawah umur pada Januari hingga awal Oktober 2020. Sedangkan pada 2019, total ada dua ratus enam kasus kriminalitas yang melibatkan anak di bawah umur, yakni ada tujuh puluh dua kasus pencurian, empat belas kasus pencabulan, Sembilan belas kasus senjata tajam, dan tujuh kasus kekerasan. "Dari tujuh kasus tersebut duabelas anak menjadi korban dan sebagian besar anak menjadi pelaku kejahatan, "Sedangkan pada 2020, tercatat empat anak menjadi korban pencabulan dan sepuluh pelaku pencabulan. Kemudian ada tujuh dua anak terlibat kasus pencurian, dan enam anak terlibat kasus penganiayaan. (Wawancara, 15 November 2020). Ia menuturkan, peningkatan kasus kriminalitas melibatkan anak tersebut disebabkan banyak hal. Seperti dampak kemajuan teknologi hingga faktor ekonomi. Untuk penanganan kasus kejahatan yang melibatkan anak di bawah umur tersebut, pihak Polres Makassar Kota bekerja sama dengan Balai Pemasyarakatan (Bapas).

Dari hasil wawancara tersebut ada peningkatan tingkat kejahatan anak dapat di analisa dengan kecendrungan anak melakukan kejahatan memiliki beberapa penyebab pengamatan penulis sendiri motivasi anak terlibat kejahatan dari keadaan lingkungan, mereka tinggal di daerah padat penduduk seperti di daerah Panakukang yang memiliki rasio penduduk bisa dikatakan padat, faktor lingkungan ini dapat mempengaruhi seseorang untuk melihat contoh kejahatan yang terjadi di sekitarnya dan mengikuti langkah kejahatan yang sama atau copy crime, selanjutnya faktor kemiskinan keterbatasan secara ekomomi dalam keluarga merupakan pengaruh yang kedua seseorang dapat melakukan kejahatan kebutuhan keluarga akan ekonomi menjadikan seseorang terdorong untuk memenuhi kebutuhan itu dengan jalan pintas untuk mendapatkan uang untuk kebutuhan keluarga atau membantu keluarga, kedua faktor ini mempengaruhi seseorang untuk bertindak melakukan kejahatan.

b. Proses Penangan Ajudikasi, Ajudikasi dan Post Ajudikasi

Pra ajudikasi merupakan suatu tahap pada saat dimulainya proses penyidikan terhadap anak nakal oleh kepolisian. Dalam tahap ini pembimbing kemasyarakatan melaksanakan tugasnya untuk membuat laporan hasil penelitian kemasyarakatan (Litmas) atas permintaan pihak penyidik kepolisian (Soewandi, 2003). Hasil laporan penelitian kemasyarakatan tersebut nantinya juga bermanfaat untuk membantu jaksa dalam membuat tuntutan dan membantu hakim dalam membuat keputusan terhadap anak nakal tersebut. Apa sebenarnya Litmas atau Case Study itu tidak lain. Untuk menetukan diagnose atau assessment maupun untuk penentuan terapi, langkah-langkah apa setelah ada litmas sebagai hasil penelitian masalah sosial yang dihadapi anak dan strategis tugas yang bagaimana serta model-model pembinaan yang tepat bagi anak yang bersangkutan maupun untuk tahanan, Napi, dan anak didik juga bermanfaat dalam pelaksanaan proses pemberian bantuan, atau dapat dikatakan sebagai proses intervensi, ikut campur dalam pemecahan masalah dan berguna untuk evaluasi.

Ajudikasi, Setelah laporan hasil penelitian kemasyrakatan (Litmas) selesai dibuat, maka akan diserahkan kepada pihak penyidik dari kepolisian yang selanjutnya akan diberkaskan guna dilimpahkan kepada Jaksa Penuntut Umum di Pengadilan hingga turunnya penetapan siding (Mahargini, 2016).

Post Ajudikasi, Apabila anak nakal atau klien anak telah dijatuhi putusan atau vonis oleh hakim, maka pembimbing kemasyarakatan masih mempunyai tugas untuk membimbing, membantu dan mengawasi anak nakal atau kalien anak tersebut sebagaimana diatur dalam Pasal 65 huruf d dan e Undang-Undang Nomor 11 Tahun 2012 Tentang Sistem Peradilan Pidana Anak bahwa; Melakukan pendampingan, pembimbingan dan pengawasan terhadap Anak yang berdasarkan putusan pengadilan dijatuhi pidana atau dikenai tindakan dan melakukan pendampingan, pembimbingan dan pengawasan terhadap anak yang memperoleh asimilasi, pembebasan bersyarat, cuti menjelang bebas dan cuti bersyarat. 
BAPAS adalah salah satu pihak yang terlibat selama proses peradilan Anak yang berkonflik dengan hukum dari awal anak ditangkap hingga anak menyelesaikan masa hukumannya. Hal ini membuat BAPAS memiliki peran yang penting dalam proses peradilan anak yang berkonflik dengan hukum secara umum peran BAPAS dalam proses peradilan Anak yang berkonflik dengan hukum terbagi menjadi 3 tahap, yaitu tahap sebelum siding pengadilan (pra adjudikasi) yakni pengawasan dan pembimbing bagi Anak yang berkonflik dengan hukum (Nashriana, 2012).

Berdasarkan penjelasan tersebut di atas, maka dapat dikemukakan bahwa peran dan fungsi BAPAS dalam menangani perkara anak yang berkonflik dengan hukum sangat penting demi tercapainya tujuan dari system peradilan pidana anak.

Sehingga pelaksanaan fungsi kemasyarakatan dalam perlindungan diharapkan dalam suatu keputusan yang diambil oleh hakim tidak melukai rasa keadilan dan dapat terwujud system peradilan pidana yang menjamin perlindungan kepentingan terbaik bagi anak, sehingga dalam Peradilan Pidana anak adalah untuk mewujudkan peradilan yang benarbenar menjamin perlindungan kepentingan terbaik bagi anak yang berhadapan kepentingan terbaik bagi anak yang berhadapan dengan hukum sebagai penerus bangsa.

Laporan Pembimbing Kemasyarakatan untuk kepentingan persidangan sebagai berikut:

a. Data pribadi anak, keluarga, pendidikan, dan kehidupan sosial;

b. Latar belakang dilakukannya tindak pidana;

c. Keadaan korban dalam hal ada korban dalam tindak pidana terhadap tubuh atau nyawa;

d. Hal lain yang dianggap perlu;

e. Kesimpulan dan rekomendasi dari pembimbing kemasyarakatan.

Pasal 60 Ayat (3) Undang-Undang Nomor 11 Tahun 2012 Tentang Sistem Perdalilan Pidana Anak bahwa Hakim wajib mempertimbangkan laporan penelitian kemasyarakatan sebelum menjatuhkan putusan perkara. Apabila hakim tidak mempertimbangkan laporan penelitian kemasyarakat dalam putusannya, maka putusan hakim tersebut batal demi hukum. Selain itu Laporan penelitian kemasyarakat oleh Pembimbing Kemasyarakatan sangat berpengaruh terhadap sukses atau tidaknya peradilan anak.

Suksesnya peradilan anak jauh lebih banyak tergantung pada kualitas dari probation officer (petugas BAPAS) dari pada hakimnya. Peradilan anak yang tidak memiliki korps pengawasan percobaan yang membimbing dengan bijaksana dan kasih saying ke dalam lingkungan kehidupan anak dan memberikan petunjuk bagi standar pemikiran yang murni bagi anak mengenai hidup yang benar, hanyalah mengakibatkan fungsi peradilan anak menjadi kabur kalau tidak ingin menjadi sia-sia (Anggraeni U.R, 2013).

Berdasarkan penjelasan tersebut di atas dapat diperoleh pemahaman bahwa kesuksesan suatu peradilan anak tergantung pada seberapa besar kualitas dari Probation Officer (petugas BAPAS) yang dimaksud dalam hal ini adalah pembimbing Kemasyrakatan dalam pelaksanaan fungsi dalam perlindungan Hak Asasi Manusia pada system peradilan Pidana anak.
3.2 Kendala Balai Pemasyarakatan Makassar dalam perlindungan hak asasi manusia pada sistem peradilan pidana anak

Bapas Kelas I Makassar memiliki wilayah kerja yang cukup luas. Fungsinya sebagai tempat pembimbingan dalam kasus anak nakal yang telah di putus maupun dalam mendampingi anak dalam siding pengadilan menjadikanya sebagai lembaga yang dibutuhkan kinerja.Nyatanya yang sigap dan tanggap dalam hal kasus anak pada khususnya. Undang-Undang Nomor 11 tahun 2012 Pasal 4 ayat (1) menyebutkan bahwa LAPAS dan BAPAS didirikan di setiap ibukota Kabupaten atau Kotamadya dan Ayat (2) dalam hal dianggap perlu, ditingkat kecamatan atau kota administratif dapat didirikan cabang LAPAS dan cabang BAPAS. Bahwa BAPAS merupakan bagian dari system Tata Peradilan, mempunyai tugas melaksanakan pembimbing dan mendampingi anak nakal dalam proses Peradilan Anak

Dalam menjalankan tugas bimbingan dan fungsinya dalam Balai Pemasyrakatan Makassar dalam perlindungan Hak Asasi Manusia pada system Pradilan Pidana Anak. Sehingga dalam menjalankan tugas dan fungsinya didalam tubuh BAPAS mengalami kendala baik internal maupun eksternal, berdasarkan wawancara yang dilakukan penulis maka dapat diketahui bahwa kendala-kendala yang dihadapi BAPAS Makassar dalam mejalankan bimbingan baik berupa internal dan eksternal diantaranya sebagai berikut:

a) Kendala Internal yaitu;

1. Anggaran yang Terbatas;

Bapas dalam melaksanakan pembimbingan klien anak ialah mengenai dana atau biaya operasional yang terbatas, anggaran menjadi hal klasik terhambatnya kinerja Bapas, dalam meningkatkan kinerja Bapas yang sangat luas yakni 10 wilayah kabupaten dan 2 kotamadya sehingga harus membutuhkan anggaran yang tidak sedikit, mulai dari mengunjungi rumah klien anak serta sarana dan prasarana dalam melakukan pembimbingan di Bapas Kelas I Makassar yang masih kurang;

2. Sumber Daya Manusia (SDM)

Sumber daya manusia yang dimaksud ialah Pegawai yang bertugas di Balai Pemasyarakatan, salah satu aspek terpenting dari faktor pegawai adalah pengetahuanpengetahuan pegawai akan bidang pekerjaan yang dilakukan. Pekerjaan dapat dilakukan oleh pegawai jika pegawai tersebut mempunyai pengetahuan tentang tugasnya masing-masing. Selain pengetahuhan, kinerja suatu institusi ataupun kelembagaan juga dilihat dari jumlah pegawai yang akan menjalankan tugasnya mengingat Wilayah kerja Bapas Kelas I Makassar berjumlah 80 orang dengan tingkat pendidikan yang ratarata telah sarjana dan mendapatkan SK-PK pendidik yang diberikan melalui pelatihan dari tingkat pusat yang nantinya akan mempermudah untuk melaksanakan tugas

Tabel 4

Jumlah Pegawai Balai Permasyarakatan Kota Makassar Yang bertugas sebagai Pendamping Pemasyarkatan

\begin{tabular}{cccccc}
\hline \multirow{2}{*}{ Golongan } & \multicolumn{4}{c}{ Ruangan } & \multirow{2}{*}{ Jumlah } \\
\cline { 2 - 5 } & A & B & C & D & 15 \\
\hline IV & 15 & - & - & - & 47 \\
\hline III & 15 & 5 & 9 & 24 & 16 \\
\hline II & - & 10 & - & 2 & 2 \\
\hline I & - & - & - & - & 80
\end{tabular}

Sumber Data: Kaur Kepagawai Bapas Kelas I Makassar 
Berdasarkan Tabel 4 jumlah pegawai Balai Pemasyarakatan Kelas I Makassar berjumlah 80 orang yang dimana berdasarkan kepangkatannya golongan IV A terdiri dari 15 orang, golongan III A 15 Orang, III B 5 orang, III C 9 orang, dan III D 24 orang sedangkan golongan III B terdiri dari 5 orang, golongan III C 9 Orang, dan II B 10 orang, golongan II D 6 Orang dan golongan I 2 Orang.

Dari data Jumlah Pagawai Balai Pemasyarakatan Kota Makassar yang bertugas sebagai pendamping Pemasyarakatan (PK) sebanyak 80 Orang tidak sebanding dengan kasus 728 Klien anak dengan jumlah kasus dengan pegawai Balai Pemasyarakatan Kelas I Makassar. merupakan pelaksanaan teknis bimbingan kemasyarakatan sebagai bagian dari system pemasyarakatan yang mengandung aspek penegakan hukum dalam memperlakukan narapidana ataupun tersangka/terdakwa anak yang lebih bersifat mengayomi masyarakat dari gangguan kejahatan.

3. Sarana dan Prasarana

Sarana dan Prasarana dalam membimbing klien anak yang kurang. Dalam hal ini belum adanya sarana keterampilan anak seperti sarana menjahit, computer, selain itu belum adanya tempat ruangan khusus keterampilan anak untuk menyalurkan bakat dan minatnya, selain itu masih terdapat Pembimbingan Kemasyarakatan (PK) yang belum memiliki Laptop dan Printer sehingga hal tersebut menghambat kinerja Bapas Kota Makassar.

b) Faktor Eksternal yaitu;

1. Klien anak yang jarang melapor;

Penghambat BAPAS dalam melaksanakan bimbingan terhadap klien anak ialah itu sendiri yang jarangn melapor ke BAPAS dalam setiap bulan, sehingga menyukitkan pihak BAPAS untuk memantau perkembangan anak dari pendidikan maupun pekerjaannya. Berdasarkan hasil pengamatan dilapangan setelah mengunjungi rumah klien anak, selah satu yang menjadi klien anak malas melapor ialah karena pergaulan yang bebas, sebab anak tersebut jarang pulang kerumah dan memilih menginap ditempat tinggal temannya. Selain itu kesibukan anak yang bekerja membuatnya jarang untuk melapor ke BAPAS;

2. Kesadaran Hukum Orang Tua yang kurang;

Kesadaran hukum orang tua yang kurang sehingga menyulitkan pihak BAPAS untuk mendata dan memantau klien anak. Hal ini dikarenakan orang tua yang tidak menerima kedatangan dari BAPAS, selain itu orang tua anak yang tidak mengerti tentang proses hukum sehingga biasanya dari pihak BAPAS menjelaskan terlebih dahulu perihal kedatangan BAPAS terhadap orang tua anak. Berdasarkan Penjelasan diatas yang menjadi kendala dalam Pelaksanaan Fungsi Balai Pemasyarakatan (BAPAS) Makassar dalam Perlindungan Hak Asasi Manusia pada system Pidana Anak.

\section{KESIMPULAN DAN SARAN}

Berdasarkan hasil penelitian dapat disimpulkan bahwa pelaksanaan fungsi Badai Pemasyarakatan (BAPAS) Makassar Dalam Perlindungan Hak Asasi Manusia Pada Sistem Pradilan Anak yaitu melalui 3 (tiga) tahap yaitu tahap Pra ajudikasi, Tahap Ajudikasi dan Pro Ajudikasi. Dalam menjalankan perannya dalam melakukan pembimbingan terhadap anak belum sesuai yang diharapakan Faktor yang menjadi Kendala yang dihadapi BAPAS Kelas I Makassar dalam Sistem Peradilan Pidana
Anak karena rendahnya kualitas sumber daya manusia di Balai Pemasyarakatan sehingga dalam menangani perkara pidana anak tidak bertindak secara professional. Kurangnya Sarana dan Prasaran yang memadai sehingga dalam penangan perkara pidana anak belum dapat melaksanakan tugas dalam penyusunan laporan penelitian Kemasyarakatan yang tidak tepat waktu dan Faktor Internal dan Faktor Eksternal.

\section{DAFTAR PUSTAKA}

Alga, dkk, 1983, Mula Hukum, Jakarta, Binacipta.

Arif Gosita, 1999, Masalah Perlindungan Anak, Akademi Pressindo, Jakarta.

Asika Mahargini, 2016, Model Sistem Peradilan Terhadap Anak yang Berhadapan dengan Hukum dengan Pendekatan Diversi dan Restoratif Justice

Barda Nawawi Arief, 2008. Bunga Rampai Kebijakan Hukum Pidana, PT. Kencana Prenada Media Group Jakarta

Binsar Gultom, .2010. Pelanggaran HAM Dalam Hukum Keadaan Darurat di Indonesia. : PT. Gramedia Utama Pustaka, Jakarta.

Departemen Pendidikan dan Kebudayaan, Tim Penyusun Kamus Pusat Pembinaan dan Pengembangan Bahasa, Kamus Besar Bahasa Indonesia,(Jakarta: Balai Pustaka, 1999), cet-1

CM Marianti Soewandi, 2003, Buku Materi Kuliah Akademi Ilmu Pemasyarakatan Surakarta, Surakarta.

Gunarto, Peranan Bapas Dalam Perkara Anak, diunduh dari http://bangopick.wordpress.com/-2008/02/09/perananbapas-dalam-perka-ra- anak/tanggal 26 Oktober 2017

Harun Nasution, 1999 Hak Asasi Manusia Dalam Islam. : Pustaka Firdaus Jakarta

Henny Saida Flora, Keadilan Restoratif Sebagai Alternatif Dalam Penyelesaian Tindak Pidana Dan Pengaruhnya Dalam Sistem Peradilan Pidana Di Indonesia. Jurnal UBELAJ, Volume 3 Number 2, October 2018.

Idrus Affandi, 1998, Tata Negara, Jakarta, PT. Balai Pustaka (Persero).

Ikhwan, 2007. Pengadilan HAM di Indonesia Dalam Prespektif Hukum Islam, : Badan Litbang dan Diklat Departemen Agama RI, Jakarta

Jimly Asshiddiqie, 2016, Konstitusi dan Konstitusionalisme Indonesia, Jakarta, Fakuktas Universitas Indonesia.

Karen Lebacqz, 2011, Teori-teori Keadilan, Bandung, Penerbit : Nusa Media

Marlina, 2009. Peradilan Pidana Anak Di Indonesia Pengembangan Konsep Diversi dan Restorative Justice. PT Refika Aditama:Bandung

Masdar F. Maseeudi, 1999. Agama dan Hak Rakyat. : Guna Aksara, Jakarta

Miriam Budiardjo, 2004. Dasar-Dasar Ilmu Politik. PT Gramedia Pustaka Utama, Jakarta

Ni'matul Huda, 2007, Lembaga Negara Dalam Masa Transisi Demokrasi, Yogyakarta, UII Press.

Nandang Sambas, 2013, Peradilan Pidana Anak di Indonesia dan Instrumen Internasional Perlindungan Anak serta Penerapannya, Yogyajelik-Delik Khusus. : Politea, Bogor

Setya Wahyudi, 2011, Implementasi Ide Diversi dalam Pembaruan Sistemarta, Penerbit : Graha Ilmu 
Rahmad Zainuddin, 2004. Hak-hak Asasi Manusia. Yayasan Obor, Jakarta

Rahardjo Adisasmita, 2011, Pengelolaan Pendapatan \& Anggaran Daerah, Penerbit: Graha Ilmu, Yogyakarta

R. Soesilo, 2001. Pokok-Pokok Hukum Pidana; Peraturan Umum dan D Peradilan Pidana Anak di Indonesia. Genta Publishing, Yogyakarta

Sudarsono, 2003 Pengantar Tata Hukum Indonesia. PT. Rineka Cipta, Jakarta

Sumarsono A. Karim, 2003. Metode dan Teknik Penelitian Kemasyarakatan. Badan Pembinaan Sumberdaya Manusia Departemen Kehakiman dan HAM RI, Jakarta.

Padmo Wahjono, 2019, Ilmu Negara Suatu Sidtematik, Sinar Grafika.. Hal: 30.

Todung Mulya Lubis, 1999. Hak Asasi Manusia, Sinar Harapan, Jakarta

Tri Jata Ayu Pramesti, 2014. Hal-hal Penting yang Datur Dalam UU Sistem Peradilan Pidana Anak. Hukum Online..com 